\title{
REDESAIN PEMBELAJARAN PENDIDIKAN ISLAM DALAM PERSPEKTIF PEMBELAJARAN ABAD 21
}

\author{
Lilis Patimah \\ Universitas Nahdhatul Ulama Surakarta \\ Email: lilispatimah@yahoo.com
}

\begin{abstract}
Abstrak
Munculnya periode baru yang sering disebut dengan masa desrupsi menuntut sumber daya manusia memiliki kompetensi dan ketrampilan baru. Lembaga pendidikan merupakan sarana untuk menyiapkan sdm yang punya kompetensi dan ketrampilan tersebut. Oleh karena itu, lembaga pendidikan islam harus mampu menyesuaikan desain pembelajarannya agar mampu membekali siswa memiliki kompetensi dan ketrampilan yang dibutuhkan untuk hidup pada abad 21. Dalam perspektif pembelajaran abad 21, ada 4 hal penting yang harus dikembangkan oleh lembaga pendidikan islam, yaitu; critical thingking, creativity, communication, dan collaboration. Artikel ini focus pada dua aspek yaitu, bagaimana desain pembelajaran agar siswa memiliki kompetensi berpikir kritis dan bertindak kreatif. Data dikumpulkan melalui literature review dan dianalisis melalui analisis data deskriptif kualitatif. Kesimpulan menunjukkan bahwa pertama, kompetensi critical thingking dapat dicapai melalui pendekatan saintifik, Kedua, kompetensi creativity, dapat dicapai dengan cara mendesain pembelajaran sehingga dapat menghasilkan produk tertentu.
\end{abstract}

Kata Kunci: Pembelajaran abad 21, Berpikir Kritis dan Kreatif, Lembaga Pendidikan Islam

\section{REDESAIN OF ISLAMIC EDUCATION LEARNING IN 21st CENTURY LEARNING PERSPECTIVE}

Abstract

The emergence of a new period often called the desrupsi demands that human resources have new competencies and skills. Educational institutions are a means to prepare the tbsp who have the competence and skills. Therefore, Islamic educational institutions should be able to adapt their learning designs to be able to equip students with the competencies and skills needed to live in the 21 st century. In the perspective of 21 st century learning, there are 4 important things that should be developed by Islamic educational institutions, namely; critical thingking, creativity, communication, and collaboration. This article focuses on two aspects, namely, how the design of learning so that students have the competence of critical thinking and creative acting. Data were collected through literature review and analyzed through qualitative descriptive data analysis. The conclusion shows that first, critical thingking competence can be achieved through scientific approach; Secondly, creativity competence can be achieved by designing the learning so that it can produce certain product.

Keywords: 21st century learning, critical and creative thinking, Islamic educational institutions 



\section{Pendahuluan}

Sebagai Negara dengan penduduk muslim terbesar di dunia, kondisi pendidikan islam di Indonesia dapat dijadikan barometer mengenai kondisi pendidikan islam secara umum. Pendidikan islam di Indonesia merupakan subsistem pendidikan nasional. Secara khusus, penyelenggaraannya di bawah kementerian agama. Lembaga pendidikan islam di Indonesia terdiri dari RA, MI, MTs, MA dan PTKI.

Kondisi lembaga-lembaga pendidikan islam tersebut jika dibandingkan dengan lembaga pendidikan yang berada di bawah naungan kementerian pendidikan dan kebudayaan relative tertinggal, baik dari segi input, proses, maupun output. Dari segi input, para siswa yang masuk ke lembaga pendidikan Islam mayoritas merupakan anak-anak yang tidak diterima di sekolahsekolah umum. Hal ini tidak terlepas dari stigma bahwa lembaga pendidikan islam merupakan lembaga kelas dua. Dari segi proses, pembelajaran lebih bersifat normative dan lebih cenderung menghafalkan daripada melatih siswa berpikir kritis dan kreatif. Pembelajaran yang demikian itu mengakibatkan para alumni lembaga pendidikan islam tidak memiliki kemampuan untuk hidup di abad 21. Selain itu, jika dilihat dari ketercukupan 8 standar nasional pendidikan, sekolah-sekolah yang berada di bawah kementerian agama juga tertinggal. Sebagai contoh, standar sarana prasarana lembaga pendidikan islam jauh tertinggal dengan sarana prasarana yang dimiliki oleh sekolah-sekolah umum. Bahkan, dari segi standard pembiayaan, terdapat ketimpangan sangat substansial ketika sekolah-sekolah di bawah kementerian agama hanya boleh dibiaya dari dana yang bersumber dari anggaran pemerintah pusat (APBN), sedangkan sekolah-sekolah umum mendapat sumber pembiayaan baik dari pemerintah pusat (APBN) maupun pemerintah daerah (APBD). Tidak kalah penting, kondisi Sumber daya manusia (pendidik) baik secara kualifikasi maupun kompetensi, guru-guru di lembaga pendidikan Islam juga di bawah guru-guru yang ada di sekolah umum.

Untuk memulai perbaikan berbagai masalah yang ada di lembaga pendidikan islam sebagaimana di uraikan di atas, tidak ada jurus jitu yang dapat diimplementasikan dalam waktu sekejap. Perlu usaha yang sungguh-sungguh dan dalam waktu yang lama. Artikel ini berusaha memaparkan alternatif solusi dari aspek proses pembelajaran, karena menurut pandangan penulis jika proses pembelajaran diperbaiki maka dapat berdampak pada perbaikan aspek-aspek yang lain. Perbaikan proses pembelajaran akan menghasilkan output yang bagus. Dengan output yang bagus maka kepercayaan masyarakat meningkat sehingga dapat menarik bibit-bibit siswa yang baik. 
Isu yang paling hangat dalam proses pembelajaran adalah bagaimana menciptakan proses pembelajaran yang memenuhi 4 kriteria sebagai berikut; critical thingking, creativity, communication, dan collaboration. Empat prinsip ini merupakan prinsip pembalajaran yang dikenal dengan istilah pembelajaran abad 21.

\section{Tuntutan dalam Pembelajaran Abad 21}

Proses pembelajaran bertujuan agar siswa mencapai kompetensi tertentu. Kompetensi itulah yang akhirnya dapat menjadi bekal bagi siswa untuk menghadapi tuntutan hidup. Sebagaimana diketahui, abad 21 merupakan era perkembangan teknologi informasi yang memiliki tantangan yang jauh berbeda dengan abad-abad sebelumnya. Agar siswa mampu bersaing dalam abad 21 maka mereka membutuhkan kompetensi yang sesuai dengan perkembangan abad 21.

Kementerian Pendidikan dan Kebudayaan Republik Indonesia telah mengadaptasi tiga konsep pendidikan abad 21 dalam rangka mengembangkan kurikulum baru baik untuk Sekolah Dasar (SD), Sekolah Menengah Pertama (SMP), Sekolah Menengah Atas (SMA) dan Sekolah Menengah Kejuruan (SMK). Ketiga konsep tersebut adalah ketrampilan abad 21 (21st Century Skills) (Trilling dan Fadel, 2009), pendekatan saintifik (Scientific approach) (Dyer, et al., 2009) dan penilaian autentik (authentic assessment) (Wiggins dan McTighe, 2011); Ormiston, 2011; Aitken dan Pungur, 1996; Costa dan Kallick, 1992).

Tantangan hidup di abad 21 menunut para siswa memiliki berbagai komptensi diantaranya yaitu: pertama, kemampaun berpikir kritis dan pemecahan masalah (Critical-Thinking and Problem-Solving Skills). Skill ini merupakan kemampuan berfikir secara kritis, lateral, dan sistemik, terutama dalam konteks pemecahan masalah; kedua, kemampuan berkomunikasi dan bekerjasama (Communication and Collaboration Skills), yaitu mampu berkomunikasi dan berkolaborasi secara efektif dengan berbagai pihak; ketiga, kemampuan mencipta dan menemukan kebaruan (Creativity and Innovation Skills), yaitu siswa mampu mengembangkan kreativitas yang dimilikinya untuk menghasilkan berbagai terobosan yang inovatif; keempat, Literasi teknologi informasi dan komunikasi (Information and Communications Technology Literacy), yaitu siswa mampu memanfaatkan teknologi informasi dan komunikasi untuk meningkatkan kinerja dan aktivitas seharihari; kelima, Kemampuan belajar kontekstual (Contextual Learning Skills), yaitu siswa mampu menjalani aktivitas pembelajaran mandiri yang kontekstual sebagai bagian dari pengembangan pribadi; keenam, kemampuan informasi dan literasi 
media (Information and Media Literacy Skills) yaitu siswa mampu memahami dan menggunakan berbagai media komunikasi untuk menyampaikan beragam gagasan dan melaksanakan aktivitas kolaborasi serta interaksi dengan beragam pihak. (BSNP, 2010: 44-45)

Sedangkan mengacu pada paradigma pendidikan nasional, BSNP merumuskan 8 paradigma pendidikan nasional di Abad-21 sebagai berikut: 1 . Untuk menghadapi di Abad-21 yang makin syarat dengan teknologi dan sains dalam masyarakat global di dunia ini, maka pendidikan kita haruslah berorientasi pada matematika dan sains disertai dengan sains sosial dan kemanusiaan (humaniora) dengan keseimbangan yang wajar. 2. Pendidikan bukan hanya membuat seorang peserta didik berpengetahuan, melainkan juga menganut sikap keilmuan dan terhadap ilmu dan teknologi, yaitu kritis, logis, inventif dan inovatif, serta konsisten, namun disertai pula dengan kemampuan beradaptasi. Di samping memberikan ilmu dan teknologi, pendidikan ini harus disertai dengan menanamkan nilai-nilai luhur dan menumbuh kembangkan sikap terpuji untuk hidup dalam masyarakat yang sejahtera dan bahagia di lingkup nasional maupun di lingkup antarbangsa dengan saling menghormati dan saling dihormati. 3. Untuk mencapai ini mulai dari pendidikan anak usia dini, pendidikan dasar, menengah dan pendidikan tinggi haruslah merupakan suatu sistem yang tersambung erat tanpa celah, setiap jenjang menunjang penuh jenjang berikutnya, menuju ke frontier ilmu. Namun demikian, penting pula pada akhir setiap jenjang, di samping jenjang untuk ke pendidikan berikutnya, terbuka pula jenjang untuk langsung terjun ke masyarakat. 4. Bagaimanapun juga, pada setiap jenjang pendidikan perlu ditanamkan jiwa kemandirian, karena kemandirian pribadi mendasari kemandirian bangsa, kemandirian dalam melakukan kerjasama yang saling menghargai dan menghormati, untuk kepentingan bangsa. 5. Khusus di perguruan tinggi, dalam menghadapi konvergensi berbagai bidang ilmu dan teknologi, maka perlu dihindarkan spesialisasi yang terlalu awal dan terlalu tajam. 6. Dalam pelaksanaan pendidikan perlu diperhatikan kebhinnekaan etnis, budaya, agama dan sosial, terutama di jenjang pendidikan awal. Namun demikian, pelaksanaan pendidikan yang berbeda ini diarahkan menuju ke satu pola pendidikan nasional yang bermutu. 7. Untuk memungkinkan seluruh warganegara mengenyam pendidikan sampai ke jenjang pendidikan yang sesuai dengan kemampuannya, pada dasarnya pendidikan harus dilaksanakan oleh pemerintah dan masyarakat dengan mengikuti kebijakan yang ditetapkan oleh pemerintah (pusat dan daerah). 8. Untuk menjamin terlaksananya pendidikan yang berkualitas, sistem monitoring yang benar dan evaluasi yang 
berkesinambungan perlu dikembangkan dan dilaksanakan dengan konsisten. Lembaga pendidikan yang tidak menunjukkan kinerja yang baik harus dihentikan.

\section{Pengembangan Pembelajaran Abad 21 di Lembaga Pendidikan Islam}

Oleh karena itu untuk belajar sesuatu, orang tidak lagi menggantungkan sematamata pada dunia sekolah dalam arti fisik. Media pembelajaran yang bersifat virtual (maya) merupakan alternatif sumber informasi dan sumber belajar (learning resource) bagi siapa saja yang menghendakinya. Dengan demikian, jika program pembelajaran ingin memiliki legitimasi akademik yang tinggi serta memiliki relevansi dengan tuntutan masyarakat dan juga stake holder-nya, maka pembelajaran harus selalu melakukan inovasi agar tidak ketinggalan jaman. Konsekuensinya, perubahan-perubahan dalam proses pembelajaran harus dilakukan.

Proses pembelajaran dalam pendidikan Islam perlu melakukan re-design agar mampu menjawab tantangan abad 21. Merujuk pada tuntutan pembelajaran abad 21 , proses pembelajaran dalam pendidikan Islam harus mengembangkan 4 prinsip sebagai berikut; pertama, pembiasaan critical thingking skill yang dapat diterapkan melalui pendekatan saintifik. Kedua, melatih kreatifitas, sehingga pembelajaran dapat menghasilkan produk tertentu. Ketiga, communication dapat dicapai melalui pembelajaran discovery, kemampuan bahasa, dan penguasaan IT. Keempat, collaboration yang dicapai melalui kerja bersama (work in group).

\section{Membentuk Critical Thingking Skills}

Ketrampilan berpikir kritis menurut Johnshon (1992) adalah kemampuan seorang dalam mempertimbangkan, menghargai, menaksir nilai suatu hal. Tugas orang yang berfikir kritis adalah menerapkan norma dan standar yang tepat terhadap suatu hasil dan mempertimbangkan nilanya dan mengartikulasikan pertimbangan tersebut. Jadi menurut Johnson berpikir kritis adalah ketika orang bertemu dengan sesuatu hal, lalu orang tersebut tidak langsung menerima secara mentah-mentah melainkan menelaah lebih dalam hal yang datang tersebut sehingga orang tersebut bisa memahami dan menyaring hal yang datang tersebut. Kemudian jika lebih lanjut hal tersebut bisa dimaknai oleh penilaian atau pertimbangan orang tersebut.

Menurut Halpen (1996), berpikir kritis adalah memberdayakan keterampilan atau strategi kognitif dalam menentukan tujuan. Proses tersebut dilalui setelah menentukan tujuan, mempertimbangkan, dan mengacu langsung kepada sasaran merupakan bentuk berpikir yang perlu dikembangkan dalam rangka memecahkan masalah, merumuskan 
kesimpulan, mengumpulkan berbagai kemungkinan, dan membuat keputusan ketika menggunakan semua keterampilan tersebut secara efektif dalam konteks dan tipe yang tepat. Berpikir kritis juga merupakan kegiatan mengevaluasi-mempertimbangkan kesimpulan yang akan diambil manakala menentukan beberapa faktor pendukung untuk membuat keputusan. Berpikir kritis juga biasa disebut directed thinking, sebab berpikir langsung kepada fokus yang akan dituju.

Tujuan berpikir kritis sebenarnya untuk menilai suatu pemikiran, menaksir nilai bahkan mengevaluasi pelaksanaan atau praktek dari suatu pemikiran dan nilai tersebut (Sapriya, 2011). Kadang juga berpikir kritis menghasilkan ide-ide baru sehinga berpikir kritis erat hubunganya dengan berpikir kreatif. Karena ketika seseorang menghadapi suatu hal atau masalah, dalam menelaah menganalisa atau mengkritisi hal tersebut maka diperlukan usaha berpikir kreatif untuk menentukan solusi yang tepat.

Ciri orang yang berfikir kritis yaitu berpikir kritis tidak sama dengan mengakumulasi informasi. Seorang dengan daya ingat baik dan memiliki banyak fakta tidak berarti seorang pemikir kritis, yang kedua seorang pemikir kritis mampu menyimpulkan dari apa yang diketahuinya, dan mengetahui cara memanfaatkan informasi untuk memecahkan masalah, dan mencari sumber-sumber informasi yang relevan untuk dirinya, yang ketiga berpikir kritis tidak sama dengan sikap argumentative atau mengecam orang lain. Yang keempat berpikir kritis bersifat netral, objektif, tidak bias, maksudnya meskipun berpikir kritis dapat digunakan untuk menunjukkan kekeliruan atau alasan-alasan yang buruk, berpikir kritis dapat memainkan peran penting dalam kerja sama menemukan alasan yang benar maupun melakukan tugas konstruktif yang kelima pemikir kritis mampu melakukan introspeksi tentang kemungkinan bias dalam alasan yang dikemukakannya.

Untuk membentuk kemampuan berpikir kritis, seorang guru dapat menjadikan contoh-contoh kasus sebagai topik bahasan yang relevan dengan materi yang akan dipelajari sesuai dengan tujuan pembelajaran. Beri kesempatan kepada siswa berpendapat sesuai dengan cara pandangnya sendiri. Jika ingin menggali lebih dalam tentang kemampuan berpikir siswa, buatlah situasi diskusi pro dan kontra sehingga masing masing siswa dapat mempertahankan argument masing masing. Kondisikan siswa agar mereka berani untuk menyampaikan pendapatnya dengan cara berkomunikasi yang baik melalui penjelasan yang berbasis metode ilmiah. Selain sekedar menyampaikan argument, berikan kesempatan kepada siswa agar dapat 
menunjukkan rasa emphati dengan role playing, yaitu menjelaskan manfaat yang bisa dirasakan jika melakukan seperti argument yang dikatakannya.

\section{Membentuk Kreatifitas Siswa}

Berpikir kreatif adalah berpikir secara konsisten dan terus menerus menghasilkan sesuatu yang kreatif/orisinil sesuai dengan keperluan. Penelitian Brookfield (1987) menunjukkan bahwa orang yang kreatif biasanya (1) sering menolak teknik yang standar dalam menyelesaikan masalah, (2) mempunyai ketertarikan yang luas dalam masalah yang berkaitan maupun tidak berkaitan dengan dirinya, (3) mampu memandang suatu masalah dari berbagai perspektif, (4) cenderung menatap dunia secara relatif dan kontekstual, bukannya secara universal atau absolut, (5) biasanya melakukan pendekatan trial and error dalam menyelesaikan permasalahan yang memberikan alternatif, berorientasi ke depan dan bersikap optimis dalam menghadapi perubahan demi suatu kemajuan. Marzano (1988) mengatakan bahwa untuk menjadi kreatif seseorang harus: (1) bekerja di ujung kompetensi bukan di tengahnya, (2) tinjau ulang ide, (3) melakukan sesuatu karena dorongan internela dan bukan karena dorongan eksternal, (4) pola pikir divergen/ menyebar, (5) pola pikir lateral/imajinatif.
Berbagai penelitian yang dilakukan oleh para ahli psikologi terhadap orang-orang yang berpikir kreatif telah menghasilkan beberapa kriteria atau ciri-ciri orang yang kreatif. Menurut Denny dan Davis (1982) dalam penelitian terhadap para penulis dan arsitek yang kreatif melalui identifikasi oleh anggota profesi mereka menghasilkan bahwa orang yang mempunyai kreatifitas yang tinggi itu cenderung memiliki ciri-ciri: fleksibel, tidak konvensional, eksentrik (aneh), bersemangat, bebas, berpusat pada diri sendiri, bekerja keras, berdedikasi dan inteligen.

Pembelajaran kreatif mengharuskan guru untuk mampu merangsang peserta didik memunculkan kreatifitas, baik dalam konteks kreatif berfikir maupun dalam konteks kreatif melakukan sesuatu. Kreatif dalam berfikir merupakan kemampuan imajinatif namun rasional. Berfikir kreatif selalu berawal dari berfikir kritis yakni menemukan dan melahirkan sesuatu yang sebelumnya tidak ada atau memperbaiki sesuatu yang sebelumnya tidak baik. Tidak seorangpun akan mengingkari bahwa kemampuan dan ciri-ciri kepribadian sampai tingkat tertentu dipengaruhi oleh oleg faktor lingkungan seperti keluwarga dan sekolah. Kedua lingkungan pendidikan ini dapat berfungsi sebagai pendorong (press) dalam pengembangan kreatifitas anak. 
Indrawati dan Wanwan Setiawan mendefinisikan pembelajaran kreatif sebagai pembelajaran yang menstimulasi siswa untuk mengembangkan gagasannya dengan memanfaatkan sumber belajar yang ada. Pembelajaran yang kreatif mengandung makna tidak sekedar melaksanakan dan menerapkan kurikulum. Kurikulum memang merupakan dokumen dan rencana baku, namun tetap perlu dikritisi dan dikembangkan secara kreatif. Dengan demikian, ada kreativitas pengembangan kompetensi dan kreativitas dalam pelaksanaan pembelajaran di kelas termasuk pemanfaatan lingkungan sebagai sumber bahan dan sarana untuk belajar. Pembelajaran kreatif juga dimaksudkan agar guru menciptakan kegiatan belajar yang beragam sehingga memenuhi berbagai tingkat kemampuan siswa dan tipe serta gaya belajar siswa (Muhibbin Syah dan Rahayu Kariadinata, 2009).

Untuk menciptakan pembelajaran yang kreatif dibutuhkan beberapa metode atau cara yang harus dilakukan oleh para pendidik, antara lain;

1. Memberi kebebasan siswa untuk mengembangkan gagasan dan pengetahuan baru

2. Bersikap respek terhadap ide-ide siswa

3. Penghargaan pada inisiatif dan kesadaran diri siswa
4. Penekanan pada proses bukan pada penilaian hasil akhir karya siswa

5. Memberikan waktu yang cukup bagi siswa untuk berpikir dan menghasilkan karya

6. Mengajukan pertanyaan-pertanyaan untuk menggugah kreativitas siswa, seperti : "mengapa", "bagaimana", dan "apa yang terjadi jika....." dan bukan pertanyaan "apa" dan "kapan (Indrawati dan Wanwan Setiawan, 2009).

Berikut ini hal-hal yang dapat digunakan untuk mengidentifikasi guru yang kreatif, yaitu:

1. Mampu menciptakan kegiatan belajar yang beragam sehingga mampu memenuhi berbagai tingkat kemampuan siswa

2. Mampu menciptakan kegiatan belajar yang dibuat memperhatikan/ menyesuaikan dengan level perkembangan kognisi, mental dan emosi dari siswa (Indrawati dan Wanwan Setiawan, 2009).

3. Membuat alat bantu belajar yang berguna meskipun sederhana (Muhibbin Syah dan Rahayu Kariadinata, 2009).

Kreatifitas siswa hanya dapat dibentuk jika pembelajaran memberikan kesempatan kepada mereka untuk melakukan eksplorasi secara bebas, mencoba hal-hal baru, dan selalu memberikan tantangan baru. 
Selain itu, kreatifitas siswa akan terbentuk jika guru mampu menciptakan pembelajaran yang kreatif.

\section{Kesimpulan}

Abad 21 telah menyebabkan perubahan dalam berbagai aspek. Lembaga pendidikan sebagai agen of change dituntut mampu memberikan respon cepat agar alumni yang dihasilkan tidak ketinggalan bahkan mampu memandu perubahan. Abad 21 menuntut manusia memiliki kompetensi inti, yaitu; pertama, kompetensi critical thingking yang dapat diterapkan melalui pendekatan saintifik, Kedua, kompetensi creativity, sehingga pembelajaran dapat menghasilkan produk tertentu. Untuk menghasilkan dua kompetensi tersebut, lembaga pendidikan Islam dituntut untuk melakukan redesain pembelajaran yang sudah berjalan saat ini. Pembelajaran yang terlalu berorientasi pada hafalan sehingga melupakan aspek analisis dan kreatifitas tentu sudah tidak relevan lagi dengan kebutuhan abad 21 sekarang ini.

\section{Daftar Pustaka}

Aitken, Nola and Pungur, Lydia (1996) Authentic Assessment, diunduh dari www.ntu.edu.vn, Oktober 2013.

Badan Standar Nasional Pendidikan (2010). Paradigma Pendidikan Nasional Di Abad-21. Jakarta: BSNP
Costa, A. L., \& Kallick, B. (1992). Reassessing assessment. In A. L. Costa, J. A. Bellanca, \& R. Fogarty, (Eds.), If minds matter: A forward to the future, Volume II (pp. 275280). Palatine, IL: IRI/Skylight Publishing

Dyer, Jeffrey H.; Gregersen, Hal B., and Christensen, Clayton M. (2009) The innovator's DNA, Harvard Business Review, December 2009, pp. 1-10.

Indrawati dan Wanwan Setiawan, Pembelajaran Aktif, Kreatif, Efektif dan Menyenangkan t.tp. : PPPPTK IPA, 2009

Mukminan, tantangan pendidikan di abad 21, SEMINAR NASIONAL TEKNOLOGI PENDIDIKAN 2014 "Peningkatan Kualitas Pembelajaran Pendayagunaan Teknologi Pendidikan" Diselenggarakan oleh Prodi. Teknologi Pendidikan Program Pascasarjana - Universitas Negeri Surabaya 29 November 2014, Hlm 6

Ormiston, Meg (2011). Creating a DigitalRich Classroom: Teaching \& Learning in a Web 2.0 World. Solution Tree Press. pp. 2-3. ISBN 978-1-935249-87-0

Sapriya. (2012). Pendidikan IPS Konsep dan Pembelajaran. Bandung : PT. Remaja Rosdakarya.

Syah, Muhibbin dan Rahayu Kariadinata, "Pembelajaran Aktif, Kreatif, Efektif, dan Menyenangkan (PAKEM)", Bahan Pelatihan, UIN Sunan Gunung Djati, Bandung, 2009.

Wiggins, G., and McTighe, J. (2011). The Understanding by Design guide to creating highquality units. Alexandria, VA: ASCD. 